\title{
USAGE OF ENGLISH MILITARY TERMINOLOGIES AS A NEUTRAL AND COLLOQUIAL VOCABULARY
}

\author{
Nargizaxon Hashimova
}

Phd, Foreign Languages Department, Fergana State University, Uzbekistan

\section{Temurkhon Sattorov}

Second Year Master's Student, Foreign Languages Department, Fergana State University, Uzbekistan

\section{ABSTRACT}

In this article military expressions in English language and their usage in ordinary people's speech is explained. If you've been in the armed services, know an enlisted soldier, or watched movies about the military, you know that military slang is practically a second language. Military slang helps soldiers convey a lot of information very quickly and allow troops to bond in life-threatening situations. Learn more with a list of these sayings and what they mean in the context of the military.The armed services have long been a hotbed of extremely creative (and sometimes rather vulgar) language coining, all of which translates into military slang sayings that definitely stick in the mind. There are tons of military euphemisms that are so original that they've gained usage in the civilian world. Because many of these sayings contain profanity, they have been censored when necessary.

KEYWORDS: - Military expressions, military slang, vulgar, common lingo, communication, abbreviations.

\section{INTRODUCTION}

Military terminological set is used as a military slang by a group of military workers. We need to know theme owing to following purposes:

1. Understand them in movies or novels- in movies which is based on wars military workers understand each other by codes or just a single words. Military slangs is useful for them to create harmless atmosphere in the surrounding of strange audience. They have very special information which can bring a lot of devastating conditions to the country if they reveal. So encoding and decoding is very essential $n$ that sphere.

2. For Adventure. People are very curios about the way others act or talk. Troops vocabulary is like a secret and opening it gives a sense of pleasure and simultaneously enhance vocabulary base of that person.

3. To use in speech. Over time that slangs or terminologies can be used in neutral language as a daily speech or within a certain group it can be used as a jargon. 
CURRENT RESEARCH JOURNAL OF PHILOLOGICAL SCIENCES 2(11):

162-167, November 2021

DOI: https://doi.org/10.37547/philological-crjps-02-11-35

ISSN 2767-3758

(C)2021 Master Journals

Crossref do

8 Google

Accepted25 $5^{\text {th }}$ November, 2021 \& Published 30th November, 2021

Materials and Methods: For better or worse, the language of the military and of warfare in particular has greatly impacted the English language. In recent years, numerous dictionaries have been compiled in the attempt to ascertain and record the often ephemeral vocabulary associated with specific wars-not only weapons terminology and technical jargon, but also the colorful slang that inevitably characterizes every war. As Thomas E. Murray remarks in his discussion of naval fighter pilot terminology, "The study of English in [the twentieth] century has shown that members of the armed services...are especially prone to linguistic creativity," whether soldiers, sailors, or flyers [1]. Wayne Silkett adds that "few specialized vocabularies have been as similarly borrowed, copied, and altered as has the military vocabulary" [2]. That military language is exceptionally productive is not, perhaps, surprising; it makes sense that "each crisis creates its own vocabulary"[1]. Moreover, since the armed forces and its component units constitute definitive "subcultures or social groups" that "daily share a common set of experiences and, perhaps, even a world view," they "can be expected to share a common lingo"[1].

Results: Before discussing war terminology specifically, it is helpful to touch on a few general trends in English word formation. Linguist John Algeo, who has been co-editor of a regular collection of neologisms in the journal American Speech for over a decade, clarifies that "word change is very rapid, compared with grammar....Words come into being, change their uses, and pass out of existence far more readily than either sounds or grammatical constructions" (Algeo) [3].* In "Where Do All the New Words Come From?" [3], Algeo devised a method to ascertain the sources for new words from 1963 to 1973 and found that in this decade-long period, 63.9 percent of new words were composites-in other words, "compounds or forms derived by affixation" (notably this is also the chief source of new words as far back as the Old English period). Second to composites, Algeo found that 14.2 percent of the neologisms of the sample decade were shifted forms: "words...used in a new meaning and sometimes as a new part of speech, usually without any change of form." Only 9.7 percent of new words were shortenings; 6.0 percent were borrowings; and finally, 4.8 percent were blendings. Additionally, of all the new words sampled in Algeo's study, 76.7 percent turned out to be nouns, 15.2 percent were adjectives, 7.8 percent were verbs, and 0.3 percent were other parts of speech. [3]

Discussion: Military Slang for People

Even without considering a service member's rank, there are many terms that describe people who have different duties. These terms can range from teasing nicknames for new recruits or members of another of the armed forces. Military slang for people can include: 
CURRENT RESEARCH JOURNAL OF PHILOLOGICAL SCIENCES 2(11):

162-167, November 2021

DOI: https://doi.org/10.37547/philological-crjps-02-11-35

ISSN 2767-3758

(C)2021 Master Journals

Crossref do: 81 Google

Accepted25 $5^{\text {th }}$ November, 2021 \& Published $30^{\text {th }}$ November, 2021

\begin{tabular}{|l|l|}
\hline $\begin{array}{l}\text { Bolo - Someone who can't pass } \\
\text { marksmanship training }\end{array}$ & Jeep - Soldier just out of basic training \\
\hline Boot - Recruit still in boot camp & Joe - Soldier (from G.I. Joe) \\
\hline $\begin{array}{l}\text { Devil dog - Term for a member of the U.S. } \\
\text { Marine Corps }\end{array}$ & $\begin{array}{l}\text { Latrine queen - Soldier in charge of cleaning } \\
\text { the bathrooms }\end{array}$ \\
\hline $\begin{array}{l}\text { Dittybopper - A signals intelligence radio } \\
\text { operator who uses Morse code }\end{array}$ & Leatherneck - Term for a U.S. Marine \\
\hline $\begin{array}{l}\text { Expectant - A soldier who is expected to die } \\
\text { from their injuries }\end{array}$ & Oxygen thief - Recruit who talks too much \\
\hline FNG - F'ing New Guy & $\begin{array}{l}\text { Pogue - Soldier who does not serve on the } \\
\text { front lines }\end{array}$ \\
\hline $\begin{array}{l}\text { FOBbit - A soldier who stays in the forward } \\
\text { operating base and hasn't seen military } \\
\text { action yet }\end{array}$ & $\begin{array}{l}\text { POG - Person other than grunt (or person on } \\
\text { ground) }\end{array}$ \\
\hline $\begin{array}{l}\text { Grape - A term with different meanings in } \\
\text { each branch of the military: }\end{array}$ & $\begin{array}{l}\text { Polliwog - U.S. Navy sailor who has not } \\
\text { crossed the equator yet }\end{array}$ \\
\hline
\end{tabular}

\section{Military Slang for Gear and Supplies}

New service members have a lot to learn after they finish bootcamp. Learning slang for gear, supplies, and parts of a uniform can be very helpful. Here are some examples of military slang that describes what soldiers carry and wear:

\begin{tabular}{|l|l|}
\hline Bang-bang - A military-issued rifle or pistol & Leather personnel carriers - Boots \\
\hline $\begin{array}{l}\text { Black (on supplies) - Certain supplies have } \\
\text { run out }\end{array}$ & $\begin{array}{l}\text { Mae West - U.S. Navy life jacket (or a term } \\
\text { for a twisted life jacket) }\end{array}$ \\
\hline C rats - Combat rations & Meat wagon - Ambulance \\
\hline Cammies - Camouflage uniform & $\begin{array}{l}\text { Mid rats - Midnight rations for members of } \\
\text { the watch crew }\end{array}$ \\
\hline $\begin{array}{l}\text { Chest candy - Decorations or awards on an } \\
\text { officer's dress uniform }\end{array}$ & Moonbeam - Flashlight \\
\hline $\begin{array}{l}\text { Firewatch ribbon - National Defense Service } \\
\text { Medal, an award given to all service members } \\
\text { during bootcamp }\end{array}$ & People tank - Submarine (U.S. Navy) \\
\hline $\begin{array}{l}\text { Fruit salad (or salad bar) - A colorful } \\
\text { assortment of military ribbons and medals on } \\
\text { an officer's dress uniform }\end{array}$ & Rack - Bed or sleep \\
\hline $\begin{array}{l}\text { Good cookie - Good Conduct Medal (given } \\
\text { every three years without a disciplinary } \\
\text { offense) }\end{array}$ & Rain locker - Shower \\
\hline
\end{tabular}


CURRENT RESEARCH JOURNAL OF PHILOLOGICAL SCIENCES 2(11):

162-167, November 2021

DOI: https://doi.org/10.37547/philological-crjps-02-11-35

ISSN 2767-3758

(C)2021 Master Journals

crossref do) 8: Google

Accepted $25^{\text {th }}$ November, 2021 \& Published $30^{\text {th }}$ November, 2021

\begin{tabular}{|l|l|}
\hline Jammin' Jenny - M16 rifle & $\begin{array}{l}\text { Scrambled eggs - Gold decorations across the } \\
\text { bill of a U.S. Navy officer's hat }\end{array}$ \\
\hline John Wayne - Can opener issued with rations & Leather personnel carriers - Boots \\
\hline
\end{tabular}

\section{Military Slang From the NATO Alphabet}

Branches of the military use the NATO phonetic alphabet to communicate in coded or high-stakes situations. Many slang sayings have come from these codes and are colorfully used by service members in different situations. Some examples of slang from the NATO alphabet include:

\begin{tabular}{|l|l|}
\hline $\begin{array}{l}\text { Alpha Charlie - A vulgar term for being } \\
\text { verbally reprimanded (ass chewing) }\end{array}$ & Mike - A minute \\
\hline $\begin{array}{l}\text { Blue Falcon - Someone who betrays you } \\
\text { (buddy f'er) }\end{array}$ & NEGAT Bravo Zulu - Not well done \\
\hline $\begin{array}{l}\text { Bravo Zulu - A compliment meaning "well } \\
\text { done" }\end{array}$ & Oscar Mike - On the move \\
\hline $\begin{array}{l}\text { Charlie Foxtrot - A vulgar term for a messed } \\
\text { up situation (a "clusterf--") }\end{array}$ & Tango Mike - Thanks much \\
\hline Charlie Mike - Continue mission & $\begin{array}{l}\text { Tango Uniform - A failed operation (one that } \\
\text { went "t--s Up) }\end{array}$ \\
\hline
\end{tabular}

\section{Military Slang for Orders and Operations}

Understanding your commanding officer's orders can be a matter of life and death. That's why many terms regarding orders and operations are in shorthand and have become slang among service members. Some of this slang includes:

\begin{tabular}{|l|l|}
\hline Bag your bandit - Shoot an enemy down & Hangfire - Wait for orders \\
\hline $\begin{array}{l}\text { Barney style - A method of explaining an } \\
\text { order in very simplistic terms }\end{array}$ & Hit the silk - Parachuting from an aircraft \\
\hline Dustoff - Medical rescue via helicopter & Kinetic - Violent \\
\hline Field op - Field operation (training exercise) & Klick (or click) - Kilometer \\
\hline
\end{tabular}

\section{Military Slang for Everyday Life}

Military slang is like a second language for soldiers. Slang can cover everyday actions, places, and experiences. Some examples of military slang for everyday life include: 
CURRENT RESEARCH JOURNAL OF PHILOLOGICAL SCIENCES 2(11):

162-167, November 2021

DOI: https://doi.org/10.37547/philological-crjps-02-11-35

ISSN 2767-3758

(C)2021 Master Journals

crossref do) 801 Google

Accepted25th November, 2021 \& Published $30^{\text {th }}$ November, 2021

\begin{tabular}{|l|l|}
\hline Big voice - Voice over a loudspeaker & Gone Elvis - Missing in action (MIA) \\
\hline Crumb catcher - Someone's mouth & Hawk - Cold weather \\
\hline $\begin{array}{l}\text { Dear John letter - Communication from a } \\
\text { soldier's significant other who wants to end } \\
\text { the relationship during enlistment }\end{array}$ & $\begin{array}{l}\text { High and tight - Term that refers to the U.S. } \\
\text { Marine buzz haircut }\end{array}$ \\
\hline $\begin{array}{l}\text { Errr - Greeting in the U.S. Marines (short for } \\
\text { "Oorah") }\end{array}$ & Hit the head - Go to the bathroom \\
\hline $\begin{array}{l}\text { Fang - To rebuke or disparage a fellow } \\
\text { soldier }\end{array}$ & $\begin{array}{l}\text { Hooah - Affirmative and/or enthusiastic } \\
\text { response in the U.S. Army }\end{array}$ \\
\hline Five-sided puzzle palace - The Pentagon & Ink stick - Pen (in the U.S. Marine Corps) \\
\hline $\begin{array}{l}\text { FOB - Forward operating base } \\
\text { Football bat - Criticism of an order or action } \\
\text { that doesn't seem to make sense }\end{array}$ & $\begin{array}{l}\text { Ooss hall - Hall where service members eat } \\
\text { their meals } \\
\text { response in the U.S. Marines }\end{array}$ \\
\hline $\begin{array}{l}\text { Fugazi - Messed-up situation } \\
\text { Oonthusiastic } \\
\text { bribe "pogues" to participate in missions }\end{array}$ \\
\hline $\begin{array}{l}\text { Gaggle march (pronounced "harch") } \\
\text { Marching out of step with your fellow } \\
\text { soldiers }\end{array}$ & Gone Elvis - Missing in action (MIA) \\
\hline $\begin{array}{l}\text { Gedunk - Junk food from a vending machine } \\
\text { or convenience store (also a term for a new } \\
\text { recruit) }\end{array}$ & Hawk - Cold weather \\
\hline $\begin{array}{l}\text { GI party - Cleaning barracks before } \\
\text { inspection }\end{array}$ & $\begin{array}{l}\text { High and tight - Term that refers to the U.S. } \\
\text { Marine buzz haircut }\end{array}$ \\
\hline
\end{tabular}

\section{Military Slang Acronyms}

Much of military slang is found in acronyms. You'll also find the majority of profane slang here, as it's much easier to hide these words in an acronym! Check out these examples of military slang acronyms:

\begin{tabular}{|l|l|}
\hline $\begin{array}{l}\text { ASAP - Immediately (as soon as possible in } \\
\text { non-military contexts) }\end{array}$ & $\begin{array}{l}\text { FUBAR - F'ed up beyond all repair (or } \\
\text { recognition) }\end{array}$ \\
\hline BOHICA - Bend over, here it comes again & $\begin{array}{l}\text { GI - Government issue, a term for soldiers } \\
\text { who feel interchangeable }\end{array}$ \\
\hline DEROS - Date estimated return overseas & ROAD Warrior - Retired on active duty \\
\hline $\begin{array}{l}\text { FIGMO - Finally, I got my orders (or F* it, } \\
\text { got my orders) }\end{array}$ & SNAFU - Situation normal: all f'ed up \\
\hline FTA - Failure to adapt (or F* the Army) & SUSFU - Situation unchanged: still f'ed up \\
\hline
\end{tabular}


CURRENT RESEARCH JOURNAL OF PHILOLOGICAL SCIENCES 2(11):

162-167, November 2021

DOI: https://doi.org/10.37547/philological-crjps-02-11-35

ISSN 2767-3758

(C)2021 Master Journals

crossref do) 8: Google

Accepted25th November, 2021 \& Published $30^{\text {th }}$ November, 2021

\section{Conclusions}

Serving in the military requires discipline, bravery, and the utmost communication. That's why military slang, expressions, and abbreviations are especially important to understand. An article that lists military acronyms can help you sort through some of the commonly confused abbreviations in the armed services. Clearly, the major challenge for addressing the impact of warfare and military terminology on the English language is one of scope. Military terminology is incredibly flexible. Not only are different military groups and, indeed, different wars characterized by particular vocabularies, military terminology also infiltrates the language of civilians and, conversely, is impacted by a number of specialized civilian vocabularies. Although this article makes no attempt to cover all of the loci of linguistic creativity marked by military terminology and the language of warfare, it offers a snapshot of the ubiquity of military discourse and its clear impact on the development of English vocabulary.

\section{REFERENCES}

1. Murray, Thomas E. "The Language of Naval Fighter Pilots." American Speech 61.2 (1986): 1 [121][ 29].

2. Algeo, John. "Where Do All the New Words Come From?" American Speech 55.4 (1980): 2[264][ 77].

3. Algeo, John, and Adele Algeo. "Among the New Words." American Speech 66.4 (1991): 3 [380] [406].

4. "Among the New Words." American Speech 67.1 (1992): 4 [83-93.]

5. Gilliland, C. Herbert. "U.S. Naval Slang: Shitcan." American Speech 55.2 (1980):.

6. Koller, Veronika. "Businesswomen and War Metaphors: 'Possessive, Jealous, and Pugnacious'?"
7. Journal of Sociolinguistics 8.1 (2004)

8. Linville, Susan E. "The "Mother" of all Battles': 'Courage Under Fire' and the Gender

9. Integrated Military." Cinema Journal 39.2 (2000).

10. Maurer, D.W. "Language and the Sex Revolution: World War I through World War II."

11. American Speech $51.1 / 2$ (1976).

12. Norris, Margot. "Military Censorship and the Body Count in the Persian Gulf War." Cultural Critique 19 (1991)

13. Silkett, Wayne A. Words of War. Military Affairs 49.1 (1985)

14. Trnka, Susanna. "Living a Life of Sex and Danger: Women, Warfare, and Sex in Military Folk

15. Rhymes." Western Folklore 54.3 (1995)

16. StatCounter - Free Web Tracker and Counter. 